\title{
Article \\ Cold Enrichment Methods for the Detection of Foodborne Yersiniosis: Friend or Foe?
}

\author{
Yuwei Zhang ${ }^{\dagger}$ and Stephen L. W. On ${ }^{*}+{ }^{+}$ \\ Department of Wine, Food and Molecular Biosciences, Lincoln University, P.O. Box 85054, \\ Lincoln 7647, New Zealand; yuwei.zhang@lincolnuni.ac.nz \\ * Correspondence: stephen.on@lincoln.ac.nz \\ + These authors contributed equally to this work.
}

check for updates

Citation: Zhang, Y.; On, S.L.W. Cold Enrichment Methods for the Detection of Foodborne Yersiniosis: Friend or Foe? Pathogens 2022, 11, 278. https://doi.org/10.3390/ pathogens 11020278

Academic Editor:

Agata Bancerz-Kisiel

Received: 2 February 2022

Accepted: 18 February 2022

Published: 21 February 2022

Publisher's Note: MDPI stays neutral with regard to jurisdictional claims in published maps and institutional affiliations.

Copyright: (C) 2022 by the authors. Licensee MDPI, Basel, Switzerland. This article is an open access article distributed under the terms and conditions of the Creative Commons Attribution (CC BY) license (https:// creativecommons.org/licenses/by/ $4.0 /)$.

\begin{abstract}
Yersinia enterocolitica and Y. pseudotuberculosis are important causes of enteric illness worldwide. Rapid response to suspected foodborne outbreaks is hampered by the widespread use of cold enrichment methods that require incubation periods of 10-21 days. Although these species grow faster at elevated temperatures, part of the rationale for cold enrichment is that a key pathogenicity marker (pYV virulence plasmid) is said to be lost at elevated temperatures. Experimental data on this claim seems scarce. We previously described an approach involving an enrichment step at $37^{\circ} \mathrm{C}$ for Yersinia detection, applied this approach to additional strains, and examined the presence of plasmids in reisolates, as well as those recovered in our original study. Plasmids were recovered from every reisolate examined; the presence of marker genes yad $\mathrm{A}$ and $v i r \mathrm{~F}$ denoted the virulence plasmid in 10 of the 11 strains examined. Use of an enrichment step at $37^{\circ} \mathrm{C}$ does not appear to promote loss of the pYV or other plasmids harboured by foodborne pathogenic $Y$. enterocolitica and Y. pseudotuberculosis; wider adoption of this approach may assist the development of more rapid detection methods.
\end{abstract}

Keywords: Yersinia; isolation; virulence plasmid

\section{Introduction}

In several countries (including New Zealand), the enteric disorder yersiniosis caused by Yersinia enterocolitica or Y. pseudotuberculosis is among the most frequently reported foodborne diseases, representing a substantive public health burden [1-4]. Detection of these species is hampered by poorly effective methods, most frequently involving cold (4-10 ${ }^{\circ} \mathrm{C}$ ) enrichment approaches for prolonged (10-21 days) periods [5], that are clearly inadequate for rapid outbreak detection. While yersiniae grow more readily at higher temperatures [6], one of the reasons that such enrichment protocols are not adopted appears to be a long-standing belief that a key pathogenicity trait (virulence plasmid pYV) is lost at such temperatures [6,7]. Clearly, optimal characterisation of an outbreak caused by pathogenic Yersinia species may not be achieved where such an important virulence trait is lost, especially when pathogenicity genes located on the plasmid can be targets for PCR detection approaches [5].

We recently described a novel, rapid $(39 \mathrm{~h})$ detection approach for Yersinia spp. in pork mince using an initial enrichment step at $37{ }^{\circ} \mathrm{C}$ combined with non-destructive, semi-automated isolate identification using Elastic Light Scatter analysis [8]. One of the anonymous referees for this paper explicitly questioned our method, declaring that "pYV could be lost and the colony morphology might be greatly affected." The reviewer furthermore suggested "Most colonies obtained from the unadulterated nutrient-enrichment method, may not be pathogens." Such a viewpoint is clearly widespread: an extensive review of Yersinia detection methods does not describe a single culture approach utilising any temperature higher than $30^{\circ} \mathrm{C}$ [5]. 
In this paper, we investigate the impact of our protocol on pYV plasmid carriage, with special reference to the enrichment temperature of $37^{\circ} \mathrm{C}$ used.

\section{Results and Discussion}

2.1. Plasmid Carriage in Y. enterocolitica and Y. pseudotuberculosis Strains Recovered Using the $37^{\circ} \mathrm{C}+28^{\circ} \mathrm{C}$ Enrichment Protocol

Sixteen isolates representing one strain each of Y. enterocolitica and Y.pseudotuberculosis recovered from our original seeding experiments [8], and nine additional strains (see Section 3, Materials and Methods) subjected to the $37^{\circ} \mathrm{C}+28{ }^{\circ} \mathrm{C}$ enrichment protocol described, were examined for plasmid carriage using the QIAPrep spin miniprep assay. Plasmids were detected in every isolate examined both pre- and post-enrichment (Figure 1).

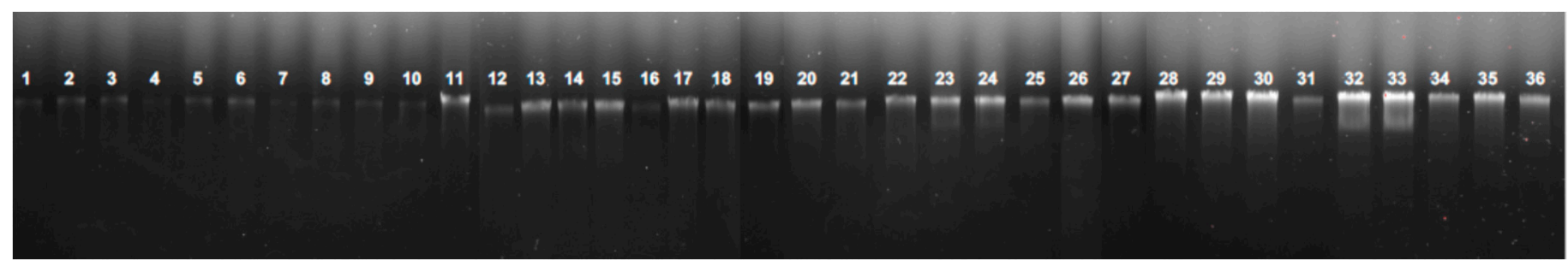

Figure 1. Plasmid analyses of strains examined. Labels 1-36 are strains as follows. 1, ERL 10782 (original strain). 2, Reisolate \#11. 3, Reisolate \#12. 4, Reisolate\#17. 5, Reisolate \#28. 6, Reisolate \#87. 7, Reisolate \#55. 8, Reisolate \#56. 9, Reisolate. \#68. 10, Reisolate \#87B. 11, Reisolate \#105. 12, ERL 110237 (original strain). 13, Reisolate \#4. 14, Reisolate \#19. 15, Reisolate \#90. 16, Reisolate \#1A. 17, Reisolate \#8. 18, Reisolate \#10. 19, ERL 112277. 20, ERL 032122. 21, ERL 032123. 22, ATCC 27729. 23, EWP5. 24, PT18-1. 25, ATCC51871. 26, NCTC 11174. 27, PB1+. 28, ERL 112277 reisolate. 29, ERL 032122 reisolate. 30, ERL 032123 reisolate. 31, ATCC 27729 reisolate. 32, EWP5 reisolate. 33, PT18-1 Reisolate. 34, ATCC51871 reisolate. 35, NCTC 11174 reisolate. 36, PB1+ reisolate.

\subsection{PCR Analysis for Virulence Genes}

The presence of yadA and virF genes (markers of the pYV virulence plasmid) was determined by PCR (see Section 3, Materials and Methods). In 10 of the 11 strains examined, both genes were detected in plasmid preparations for each of these strains, thus indicating presence of the pYV plasmid (Supplementary Figure S1, Table 1); in four of the strains examined, these virulence genes were not detected in the simple heated lysates examined. For strain ERL 10782 (Y. enterocolitica), neither yadA nor virF were detected by PCR, indicating that the plasmid detected was not pYV.

Table 1. Summary of plasmid, yadA and virF gene detections by PCR among Yersinia strains examined. PCR results are presented for whole-cell heated lysates and plasmid preparations separately.

\begin{tabular}{ccccccc}
\hline Strain No. & Plasmid & yadA Plasmid & yadA Lysate & virF Plasmid & virF Lysate & Species \\
\hline ERL 10782 & + & - & - & - & - & Ye \\
\hline Reisolate \#11 & + & - & - & - & - & Ye \\
\hline Reisolate \#12 & + & - & - & - & - & Ye \\
\hline Reisolate \#17 & + & - & - & - & - & - \\
\hline Reisolate \#28 & + & - & - & - & - & Ye \\
\hline Reisolate \#87 & + & - & - & - & - & Ye \\
\hline Reisolate \#55 & + & - & - & - & Ye \\
\hline Reisolate \#56 & + & - & - & Ye \\
\hline Reisolate \#68 & + & - & - & - & - \\
\hline
\end{tabular}


Table 1. Cont.

\begin{tabular}{|c|c|c|c|c|c|c|}
\hline Strain No. & Plasmid & yadA Plasmid & yadA Lysate & virF Plasmid & virF Lysate & Species \\
\hline Reisolate \#87B & + & - & - & - & - & Ye \\
\hline Reisolate \#105 & + & - & - & - & - & $\mathrm{Ye}$ \\
\hline ERL 110237 * & + & + & + & + & + & Yp \\
\hline Reisolate \#4 & + & + & + & + & + & Yp \\
\hline Reisolate \#19 & + & + & + & + & + & $\mathrm{Yp}$ \\
\hline Reisolate \#90 & + & + & + & + & + & $Y p$ \\
\hline Reisolate \#1A & + & + & + & + & + & Yp \\
\hline Reisolate \#8 & + & + & + & + & + & $Y p$ \\
\hline Reisolate \#10 & + & + & + & + & + & Yp \\
\hline ERL 112277 & + & + & - & + & - & Ye \\
\hline ERL 032122 & + & + & + & + & + & Ye \\
\hline ERL 032123 & + & + & - & + & + & Ye \\
\hline ATCC 27729 & + & + & + & + & + & Ye \\
\hline EWP5 & + & + & - & + & - & Ye \\
\hline PT18-1 & + & + & - & + & - & Ye \\
\hline ATCC51871 & + & + & + & + & + & Ye \\
\hline NCTC 11174 & + & + & + & + & + & Ye \\
\hline PB1+ & + & + & + & + & + & $Y p$ \\
\hline
\end{tabular}

The original seeding cultures in reference [8] are denoted by an asterisk, ${ }^{*}$. Reisolates refer to strains of that strain recovered after pork mince seeding studies [8] or experiments described in this paper. + , trait detected; -, trait not detected; Ye, Y. enterocolitica; Yp, Y. pseudotuberculosis; ERL, Enteric Reference Laboratory of the Institute of Environmental Science, New Zealand; ATCC, American Type Culture Collection, Virginia, MA, USA; NCTC, National Type Culture Collection, London, UK. The strain prefixes of EWP, PT and PB are of unknown affiliation and are reproduced as received.

\subsection{Discussion}

The widespread use of the cold enrichment approach to the detection of foodborne Yersinia species may, in part, be due to statements in influential reference books that state "virulent plasmid-containing strains of Y. pestis, Y. pseudotuberculosis, and Y. enterocolitica rapidly become avirulent when grown at $37^{\circ} \mathrm{C}$, which results in the loss of the virulence plasmid" [6]. Several articles also refer to this feature [7,9,10]; however, specific experimental studies appear scarce. In one study that explicitly investigates the loss of the virulence plasmid in these species when cultured at $37^{\circ} \mathrm{C}$, the process is described as "spontaneous" rather than an event that can be reliably and repeatedly determined [7]. Elevated $\mathrm{NaCl}$ and calcium concentrations as well as acidic $(\mathrm{pH} 4-6)$ conditions have also been shown to stabilise plasmid carriage $[10,11]$. However, the conditions we used involve $\mathrm{NaCl}$ concentrations of $0.5 \%$, no additional calcium and, in the original study involving a modified Ossmer broth, a pH of 8.5 [8]. In every strain of Y. enterocolitica and Y. pseudotuberculosis we examined, plasmids were detectable from colonies examined after enrichment at $37^{\circ} \mathrm{C}$ and recovery on solid media at $28^{\circ} \mathrm{C}$. In 10 of 11 strains, the plasmid was presumed to be the virulence pYV type, on the basis of the presence of key genes yad $\mathrm{A}$ and $\operatorname{vir} \mathrm{F}$ in plasmid preparations (failure of some lysates to yield a PCR product was attributed to inhibitors that may be present in such crude preparations) (Figure S1). This suggests that the risk of strains of these foodborne pathogenic species losing this key virulence trait is low under such conditions. Conversely, such conditions are conducive to more rapid growth, enabling detection in periods as low as $39 \mathrm{~h}$ [8]. Our observation also aligns with the view that key virulence factors including yad A are expressed at $37^{\circ} \mathrm{C}$, and that the genetic structure of the plasmid is designed for optimal expression at this temperature $[9,12]$. It 
seems counter-intuitive that a key virulence trait is lost at the same temperature at which it is expressed.

The observation that one of the Y. enterocolitica strains examined by us from human diarrhoea (ERL 10782) contains a plasmid that does not appear to be the pYV variant, since neither yadA or virF were detected. Although pYV is regarded as a key virulence trait, it is not the only one, and virulent strains are known that lack this plasmid [13].

The use of low temperatures to preserve the Yersinia virulence plasmid is not the only rationale underpinning the widespread use of cold enrichment to recover these organisms from foods. Foodborne pathogenic Yersinia species may be found in foods that harbour many other bacterial species in higher numbers that may outcompete the growth of yersiniae, where higher incubation temperatures are used [9,12]. However, the apparent dominance of cold enrichment approaches to detect Yersinia in foods may be deterring researchers from exploring other approaches to enrich and/or detect these bacteria from complex matrices in a more rapid manner. We hope our study serves to demonstrate that loss of the pYV virulence factor appears to be of minimal risk when recovering Yersinia species at temperatures more conducive to organismal growth. The value of such alternatives has already been demonstrated [8]; we hope other researchers will further examine the opportunity to develop better tools for an important cause of foodborne illness worldwide.

\section{Materials and Methods}

\subsection{Strains Used}

Original cultures, as well as reisolates of strains ERL 10782 (Y. enterocolitica) and ERL 110237 (Y. pseudotuberculosis) used to seed pork mince samples in the original study [8], were studied. Additional strains of Y. enterocolitica (ERL 112277, ERL 032122, ERL 032123, EWP5, PT18-1, ATCC27729, ATCC51871, NCTC11174) and Y. pseudotuberculosis (PB1+) were also examined.

\subsection{Culture Methods}

For original cultures and reisolates of the seeding strains, isolates were subcultured twice from frozen stocks of these cultures on 5\% blood agar (Fort Richard, Auckland, New Zealand) and incubated overnight at $28{ }^{\circ} \mathrm{C}$. Thereafter, a single colony was picked and inoculated into $25 \mathrm{ml}$ nutrient broth (Oxoid no. 2, Basingstoke, UK) and cultured overnight at $37{ }^{\circ} \mathrm{C}$ with shaking at $100 \mathrm{rpm}$. Thereafter, $50 \mu \mathrm{L}$ of the enrichment was taken and inoculated onto Tryptone Soya Agar (Fort Richard, Auckland, New Zealand) for $22 \mathrm{~h}$ at $28^{\circ} \mathrm{C}$ as before [8]. Single colonies from each culture were then taken and subjected to plasmid and PCR analyses as described below.

\subsection{Plasmid DNA Isolation and Detection}

The extraction of plasmid DNA from the bacterial samples was achieved using a commercial kit (QIAprep®Spin Miniprep Kit, QIAGEN, Hilden, Germany) in accordance with the manufacturer's instructions. For detection, $10 \mu \mathrm{L}$ pDNA was loaded onto a $0.8 \%$ agarose gel and electrophoresed in $0.5 \times \mathrm{TBE}$ buffer at $90 \mathrm{~V}$ for $90 \mathrm{~min}$. Plasmid visualisation was achieved by staining with SYBRTM Safe DNA Gel Stain (Invitrogen, Thermo Fisher Scientific, Waltham, MA, USA).

\subsection{PCR Analysis}

The presence of key virulence marker genes yadA and virF was determined by PCR using methods described previously [14], with minor modifications. In brief, the primers used were: for yadA (amplicon size 849 bp), yadA-F (CTTCAGATACTGGTGTCGCTGT) and yadA-R (ATGCCTGACTAGAGCGATATCC); and for virF (amplicon size $561 \mathrm{bp}$ ), virF-F (GGCAGAACAGCAGTCAGACATA) and $v i r F-R$ (GGTGAGCATAGAGAATACGTCG). PCR reactions were undertaken on both plasmid extractions (described above) and heated lysates of colonies to examine the possibility that virulence genes may be chromosomally 
borne, were they not detected in plasmid preparations. Assays were performed in a $20 \mu \mathrm{L}$ reaction system comprising repliQa HiFi ToughMix ${ }^{\circledR}(Q u a n t a b i o$, Beverly, MA, USA): $10 \mu \mathrm{L}$, Forward primer: $1 \mu \mathrm{L}$, Reverse primer: $1 \mu \mathrm{L}$, Nuclease-free water: $6 \mu \mathrm{L}$ and Template: $2 \mu \mathrm{L}$. The concentration of pDNA stocks and cell lysates were determined by a DeNovix ${ }^{\circledR D S}-11+$ Spectrophotometer (DeNovix Inc., Wilmington, DE, USA) and adjusted to $50 \mathrm{ng} / \mu \mathrm{L}$ and $100 \mathrm{ng} / \mu \mathrm{L}$, respectively, with UltraPure ${ }^{\mathrm{TM}} \mathrm{DNase} / \mathrm{RNase}$-free distilled water (Thermo Fisher Scientific Ltd.). Hence, the starting DNA amount in each of the $20 \mu \mathrm{L}$ pDNA or heated cell lysate PCR assays was $100 \mathrm{ng}$ and $200 \mathrm{ng}$, respectively, to make the final DNA concentration in the reaction mixture at $5 \mathrm{ng} / \mu \mathrm{L}$ for those that contained pDNA, and $10 \mathrm{ng} / \mu \mathrm{L}$ for those that contained simple heated cell lysates. Products were detected by electrophoresis in a Wide mini-sub cell system (Bio-Rad, Hercules, CA, USA) using $5 \mu \mathrm{L}$ of each sample loaded onto a $1.5 \%$ agarose gel and electrophoresed for $90 \mathrm{~min}$ at $90 \mathrm{~V}$ in $0.5 \times$ TBE buffer.

Supplementary Materials: The following supporting information can be downloaded at: https: / /www.mdpi.com/article/10.3390/pathogens11020278/s1, Figure S1: PCR analyses of heated lysates and purified plasmid DNA for the presence of virulence marker genes yadA and virF.

Author Contributions: Conceptualization, Y.Z. and S.L.W.O.; methodology and laboratory analyses, Y.Z.; writing-original draft preparation, S.L.W.O.; writing-review and editing, Y.Z. and S.L.W.O.; supervision, S.L.W.O. All authors have read and agreed to the published version of the manuscript.

Funding: This research received no external funding. The APC was funded by the Lincoln University Open Access fund.

Data Availability Statement: All relevant data are published here or in the supplementary figure to this article, available online.

Acknowledgments: We thank Craig Billington (Institute of Environmental Science, Christchurch, New Zealand), Steve Flint (Massey University, Palmerston North, New Zealand) and Andrew Gehring (US Department of Agriculture, Eastern Regional Research Center, PA, USA) for their kind donations of strains used in this, and our previous study.

Conflicts of Interest: The authors declare no conflict of interest.

\section{References}

1. Centers for Disease Control. Yersinia enterocolitica. 2019. Available online: https://www.cdc.gov/yersinia/index.html (accessed on 28 August 2020).

2. European Centre for Disease Prevention and Control. Yersiniosis, 2019, ECDC, Stockholm: Annual Epidemiological Report for 2018. Available online: https:/ / www.ecdc.europa.eu/en/publications-data/yersiniosis-annual-epidemiological-report-2018 (accessed on 28 August 2020).

3. Pattis, I.; Horn, B.; Armstrong, B.; Cressey, P.; Lopez, L.; Soboleva, T. Annual Report Concerning Foodborne Diseases in New Zealand 2019; Ministry for Primary Industries: Wellington, New Zealand, 2020. Available online: https:/ /www.mpi.govt.nz/ dmsdocument/42874-Annual-report-concerning-foodborne-disease-in-New-Zealand-2019 (accessed on 28 August 2020).

4. Williamson, D.A.; Baines, S.L.; Carter, G.P.; Da Silva, A.G.; Ren, X.; Sherwood, J.; Dufour, M.; Schultz, M.B.; French, N.P.; Seemann, T.; et al. Genomic Insights into a Sustained National Outbreak of Yersinia pseudotuberculosis. Genome Biol. Evol. 2016, 8, 3806-3814. [CrossRef] [PubMed]

5. Petsios, S.; Fredriksson-Ahomaa, M.; Sakkas, H.; Papadopoulou, C. Conventional and molecular methods used in the detection and subtyping of Yersinia enterocolitica in food. Int. J. Food Microbiol. 2016, 237, 55-72. [CrossRef] [PubMed]

6. Bottone, E.J.; Bercovier, H.; Mollaret, H.H. Genus XLI. Yersinia. In Bergey's Manual of Systematic Bacteriology; Brenner, D.J., Krieg, N.R., Staley, J.T., Garrity, G.M., Eds.; Springer: New York, NY, USA, 2005; pp. 838-848.

7. Bhaduri, S.; Smith, J.L. Virulence Plasmid (pYV)-Associated Expression of Phenotypic Virulent Determinants in Pathogenic Yersinia Species: A Convenient Method for Monitoring the Presence of pYV under Culture Conditions and Its Application for Isolation/Detection of Yersinia pestis in Food. J. Pathog. 2011, 2011, 727313. [PubMed]

8. On, S.L.W.; Zhang, Y.; Gehring, A.; Patsekin, P.; Chelikani, V.; Flint, S.; Wang, H.; Billington, C.; Fletcher, G.C.; Lindsay JRobinson, J.P. Elastic Light Scatter pattern analysis for the expedited detection of Yersinia species in pork mince: Proof of concept. Front. Microbiol. 2021, 12, 290. [CrossRef] [PubMed]

9. Bottone, E.J. Yersinia enterocolitica: The charisma continues. Clin. Microbiol. Rev. 1997, 10, 257-276. [CrossRef] [PubMed]

10. Li, H.; Bhaduri, S.; Magee, W.E. Maximizing plasmid stability and production of released proteins in Yersinia enterocolitica. Appl. Environ. Microbiol. 1998, 64, 1812-1815. [CrossRef] [PubMed] 
11. Bhaduri, S. Effect of salt and acidic $\mathrm{pH}$ on the stability of virulence plasmid (pYV) in Yersinia enterocolitica and expression of virulence-associated characteristics. Food Microbiol. 2011, 28, 171-173. [CrossRef]

12. Rohde, J.R.; Luan, X.S.; Rohde, H.; Fox, J.M.; Minnich, A.S. The Yersinia enterocolitica pYV virulence plasmid contains multiple intrinsic DNA bends which melt at 37 degrees C. J. Bacteriol. 1999, 181, 4198-4204. [CrossRef]

13. Razzuoli, E.; Vencia, W.; Modesto, P.; Franzoni, G.; Giudici, S.D.; Parisi, E.; Ferrari, A.; Amadori, M. Yersinia enterocolitica-specific modulation of innate immune responses in jejunal epithelial cells. Vet. Microbiol. 2020, 242, 108596. [CrossRef] [PubMed]

14. Thoerner, P.; Bin Kingombe, C.I.; Bogli-Stuber, K.; Bissig-Choisat, B.; Wassenaar, T.M.; Frey, J.; Jemmi, T. PCR detection of virulence genes in Yersinia enterocolitica and Yersinia pseudotuberculosis and investigation of virulence gene distribution. Appl. Environ. Microbiol. 2003, 69, 1810-1816. [CrossRef] [PubMed] 